\title{
PEMANFAATAN BAYAM MERAH (BLITUM RUBRUM) UNTUK MENINGKATKAN KADAR ZAT BESI DAN SERAT PADA MIE KERING
}

\author{
USE OF SPINACH RED (BLITUM RUBRUM) \\ TO INCREASE LEVELS IRON AND FIBER ON DRY NOODLE
}

Disusun Oleh :

\author{
I Komang Suwita, Maryam Razak, Rizqa Andari Putri \\ Jurusan Gizi Politeknik Kesehatan Kemenkes Malang
}

\begin{abstract}
ABSTRAK
Penelitian ini bertujuan menganalisis pengaruh penambahan bayam merah (Blitum rubrum) terhadap kadar zat besi, kadar serat, kadar air, mutu organoleptik, mutu fisik dan menetukan taraf perlakuan terbaik dari proporsi penambahan daun bayam merah pada mie kering. Jenis penelitian adalah penelitian eksperimen laboratorium dengan desain percobaan Rancangan Acak Lengkap (RAL). Analisis statistik yang digunakan untuk kadar zat besi, kadar serat, kadar air dan mutu fisik (daya putus) adalah One Way Anova, sedangkan untuk mutu organoleptik adalah Kruskall Wallis dengan tingkat kepercayaan 95\%. Perlakuan penelitian adalah penambahan bayam merah ke dalam mie kering dengan 6 taraf perlakuan yaitu penambahan bayam merah dengan proporsi $0 \%$, 20\%, 25\%, 30\%, 35\%, dan 40\% dengan replikasi sebanyak 3 kali setiap taraf perlakuan. Hasil penelitian menunjukkan bahwa semakin tinggi penambahan bayam merah ke dalam mie kering maka kadar zat besi, kadar serat, kadar air serta mutu fisik (daya putus) semakin meningkat. Hasil analisis penilaian mutu organoleptik menunjukkan bahwa semakin tinggi penambahan bayam merah maka persentase penerimaan panelis terhadap tekstur, rasa, dan warna meningkat namun persentase penerimaan panelis terhadap aroma menurun. Penilaian perlakuan terbaik menunjukkan bahwa taraf perlakuan $\mathrm{P}_{5}$ (penambahan bayam merah 40\%) dapat direkomendasikan menjadi taraf perlakuan terbaik. Taraf perlakuan $\mathrm{P}_{5}$ (penambahan bayam merah $40 \%$ ) dapat dimanfaatkan sebagai sumber untuk memenuhi zat besi dalam rangka menanggulangi masalah anemia zat besii.
\end{abstract}

Kata kunci : Bayam merah, Mie kering, Zat Besi, Mutu Organoleptik, Mutu Fisik.

\begin{abstract}
This study aims to analyze the effect of the addition of red amaranth (Blitum rubrum) on levels of iron, fiber content, water content, organoleptic quality, level of physical quality and determine the best treatment of the proportion of red on the addition of spinach leaves dry noodles. This type of research is experimental research laboratory experimental design with completely randomized design (CRD). Statistical analysis is used for iron levels, fiber content, water content and physical quality (power off) is a One Way ANOVA, while for organoleptic quality is Kruskall Wallis with a 95\% confidence level. Treatment research is the addition of red spinach into dry noodles with 6 standard treatment with the addition of red spinach proportion of $0 \%, 20 \%, 25 \%, 30 \%, 35 \%$, and $40 \%$ with replication 3 times each stage of treatment. The results showed that the higher the addition of red spinach in to dried noodles the levels of iron, fiber content, water content and the physical quality (power off) increasing. Organoleptic quality assessment analysis results showed that the higher the percentage the addition of red spinach panelists acceptance of the texture, flavor, and color to increase the percentage of revenue decreased panelists for aroma. The best treatment assessment showed that the level of treatment P5 (the addition of red spinach 40\%) can be recommended as the best standard treatment. P5 level treatment (addition of red spinach $40 \%$ ) can be utilized as a source of fulfillment to address the problem of iron anemi.
\end{abstract}

Keywords: red spinach, dried noodles, Iron, Quality Organoleptic, Physical Quality. 


\section{PENDAHULUAN}

Bayam merah (Celosia argentea) merupakan tumbuhan dari keluarga Amaranthacea. Nama saintifiknya adalah Amaranthacea Gangeticus dan nama Inggrisnya Red Spinach. Di Jawa, tanaman ini dinamai bayem abrit, bayem lemag atau bayem sekul.

Namun, tak dipungkiri bahwa mayoritas masyarakat kita tak banyak mengenal bayam merah. Masyarakat lebih familiar dengan bayam hijau untuk konsumsi sehari-hari. Ketidak populeran bayam merah berakibat pada budidaya maupun pemasarannya juga belum begitu masif. Padahal, tanaman bernama latin alternanthera amoena voss ini mengandung banyak khasiat yang dapat mengobati berbagai penyakit. Bahkan, bayam merah dipercaya juga dapat membersihkan darah setelah melahirkan, memperkuat akar rambut, mengobati disentri, dan mengatasi anemia (Doktersehat.com, 2012)

Anemia gizi sangat umum dijumpai di Indonesia. Dari segi kesehatan masyarakat, anemia gizi terutama disebabkan karena kekurangan zat besi, sehingga anemia gizi sering disebut sebagai anemia kurang besi (Husaini, 1989). Anemia karena defisiensi zat besi merupakan penyebab utama anemia pada ibu hamil dibandingkan dengan defisiensi zat gizi lain. Diungkapkan oleh Simanjuntak (1992) dalam Amiruddin (2007), bahwa sekitar 70\% ibu hamil di Indonesia menderita anemia defisiensi zat besi. Anemia defisiensi zat besi merupakan masalah gizi yang paling lazim di dunia dan menjangkiti lebih dari 600 juta manusia. Dengan frekuensi yang masih cukup tinggi, berkisar antara 10\% hingga 20\% (Prawirohardjo, 2002 dalam Amiruddin, 2007).
Badan kesehatan dunia/World Health Organization dalam Amiruddin (2007) melaporkan bahwa anemia defisiensi zat besi lebih cenderung terjadi di negara yang sedang berkembang daripada negara yang sudah maju. Di negara yang sedang berkembang dari perkiraan populasi 3800 juta orang, $36 \% \quad( \pm 1400$ juta orang) menderita anemia defisiensi zat besi, sedangkan di negara maju hanya $8 \%$ ( \pm 100 juta orang) dari populasi 1200 juta orang. Menurut Hasil Survey Kesehatan Rumah Tangga (2001), prevalensi anemia pada kehamilan di Indonesia masih tinggi yaitu sekitar 40,1\%. Kira-kira satu dari dua wanita di Indonesia beresiko terkena anemia defisiensi zat besi selama masa kehamilan (Brown, 2005).

Prevalensi anemia defisiensi zat besi yang tinggi ini dapat membawa akibat negatif seperti rendahnya kemampuan kerja jasmani dan produktivitas kerja, rendahnya kemampuan intelektual dan rendahnya kekebalan tubuh, sehingga menyebabkan tingginya angka kesakitan. Dengan demikian konsekuensi fungsional dari anemia defisiensi zat besi menyebabkan turunnya kualitas sumber daya manusia. Secara ideal untuk mengatasi masalah anemia defisiensi zat besi adalah dengan suplementasi atau pemberian preparat besi dalam bentuk sirup atau pil sebagai obat, namun program ini masih dirasakan kurang efektif terutama karena masalah distribusi (Husaini, 1989).

Bayam terkenal dengan sayuran sumber zat besi, selain mengandung vitamin $\mathrm{A}$, vitamin $\mathrm{C}$, dan kalsium (Smith, 2002). Purnawijayanti (2009), juga menyebutkan bahwa bayam mengandung karotenoid dan flavonoid 
yang merupakan zat aktif dengan khasiat antioksidan. Jenis karotenoid utama dalam bayam adalah beta karoten, sedangkan zat aktif lainnya adalah klorofil. Jenis flavonoid yang terkandung di dalam bayam adalah lutein dan kuersetin. Kuersetin merupakan antioksidan kuat yang mampu menangkap radikal bebas superoksida dan menghambat oksidasi kolesterol LDL. Lebih lanjut dikatakan bahwa ada dua jenis bayam, yaitu bayam hijau dan bayam merah. Keduanya kaya vitamin C, tetapi bayam hijau lebih kaya vitamin A sedangkan bayam merah lebih banyak mengandung zat besi.

Berdasarkan kandungan zat besi yang terkandung pada bayam merah (7 $\mathrm{mg} / 100$ g) yang lebih banyak dibandingkan sayur-sayuran lainnya, maka bayam merah dapat dimanfaatkan dengan baik sebagai bahan alternative untuk mencegah dan mengatasi anemia defisiensi zat besi. Selain itu Indonesia memiliki potensi untuk mengembangkan produk-produk dengan bahan dasar bayam dikarenakan jumlah produksi yang relatif meningkat tiap tahunnya yaitu 149.435 - 163.817 ton pada periode tahun 2006 - 2008. Begitu pula dengan produksi bayam di Jawa Timur yang juga relatif meningkat tiap tahunnya yaitu 2233 - 2423 ton pada periode tahun 2006 - 2008 (Kementrian Pertanian Republik Indonesia, 2010). Diperlukan suatu alternatif dalam pengolahan bayam merah agar masyarakat bisa mengkonsumsinya dalam bentuk yang lain. Salah satu makanan yang disukai dan sering dijumpai di masyarakat dengan harga terjangkau adalah mie. Namun, pembuatan mie selama ini banyak memakai bahan pewarna dan bahan pengawet seperti natrium benzoate (Winarno, 2002).

Menurut Subijakto (2010), sebagian masyakat Indonesia mengkonsumsi mie tanpa penambahan bahan makanan lain, bahkan ada yang menggunakan mie sebagai lauk ataupun sayur berkuah yang digunakan sebagai teman nasi dalam konsumsi sehari-hari, padahal sebagian besar kandungan mie adalah karbohidrat. Selain itu Purnawijayanti (2009) juga menjelaskan bahwa mie memiliki kandungan protein, vitamin, dan mineral yang cukup rendah. Bahkan mie tidak mengandung serat makanan (dietary fiber) yang baik untuk kesehatan pencernaan. Demikian pula, mie relatif tidak mengandung senyawa-senyawa aktif yang dapat mendukung tercapainya kesehatan yang baik. Oleh karena itu perlu dikaji dalam suatu penelitian penambahan bayam merah ke dalam pengolahan mie agar dapat digunakan sebagai salah satu alternatif dalam pencegahan anemia defisiensi zat besi karena kandungan zat besi dalam bayam merah yang cukup tinggi.

Tujuan penelitian ini adalah : menganalisis pengaruh penambahan bayam merah (Blitum rubrum) terhadap kadar zat besi, kadar serat, kadar air, mutu organoleptik, dan mutu fisik mie kering.

\section{METODE PENELITIAN}

Penelitian ini dilaksanakan pada bulan Januari - Maret 2011, di Laboratorium Ilmu Bahan Makanan (IBM) Jurusan Gizi Politeknik Kesehatan Kemenkes Malang untuk penelitian utama, meliputi pengolahan mie dengan penambahan bayam merah dan pengujian organoleptik, serta 
analisis kadar serat, dan kadar air. Dan dilaksanakan di Laboratorium Kimia Universitas Muhamadiyah Malang untuk analisis kadar zat besi dan daya putus mie.

Bahan yang digunakan dalam pembuatan mie adalah: daun bayam merah, tepung terigu protein tinggi, tepung tapioka, tepung pati, telur, soda abu/air qi, CMC/STPP, dan garam dapur.

Bahan untuk analisis adalah: mie kering berdasarkan proporsi penambahan bayam merah, $\mathrm{Fe}\left(\mathrm{SO}_{4}\right)_{2}$, larutan tyocyanat, larutan standar $\mathrm{Fe}$ (0,1 mg), $\mathrm{H}_{2} \mathrm{SO}_{4}, \quad \mathrm{~K}_{2} \mathrm{~S}_{2} \mathrm{O}_{8}, \mathrm{NaOH}$, $\mathrm{K}_{2} \mathrm{SO}_{4} 10 \%$, dan alkohol 95\%.

Alat-alat yang digunakan dalam penelitian ini antara lain; timbangan analitik, pasta machine, mixer, gelas ukur, dandang, kompor gas, sendok, blender, piring, baskom, pisau, oven, kurs porselen, eksikator, penjepit cawan, spektrofotometer, kuvet, buret, tabung reaksi dan rak, labu seukuran, gelas kimia, corong, batang pengaduk, pipet volume, karet pompa, dan gelas arloji, penggiling, soxhlet, erlenmeyer $600 \mathrm{ml}$, pendingin balik, kertas saring, spatula, gelas berisi air minum, form daya terima panelis, alat tulis, sendok, dan nampan, alat pengukur elastisitas.

Jenis penelitian ini adalah penelitian eksperimen laboratorium dengan desain percobaan Rancangan Acak Lengkap (RAL) dengan 6 taraf perlakuan, yaitu penambahan bayam merah dengan proporsi $0 \%, 20 \%, 25 \%$, $30 \%$, 35\%, dan 40\%. Dalam masingmasing taraf perlakuan dilakukan replikasi sebanyak 3 kali.

Dengan menggunakan prinsip permutasi sederhana, maka nomor rangking dapat dianggap mewakili nomor urut sesuai dengan jumlah unit penelitian. Dengan demikian, semua taraf perlakuan, mulai taraf perlakuan $\mathrm{P}_{0}, \mathrm{P}_{1}, \mathrm{P}_{2}, \mathrm{P}_{3}, \mathrm{P}_{4}$ dan $\mathrm{P}_{5}$ masing-masing diulang 3 kali

\section{Penelitian Pendahuluan}

Penelitian pendahuluan dilaksanakan bertujuan untuk mengetahui proporsi penambahan bayam merah yang dapat diterima oleh panelis. Hasil penilaian panelis digunakan untuk penelitian utama.

\section{Penelitian Utama}

Penelitian utama dilakukan dalam 3 tahap, yaitu : 1) Persiapan Bahan, bayam merah diblanching kurang lebih 3 menit pada suhu $85^{\circ} \mathrm{C}$, kemudian diblender dengan penambahan air 28\% dari berat tepung, 2) Formulasi bahan utama yaitu tepung terigu, tepung tapioka, tepung pati, bahan pengenyal (STPP/CMC), garam, air qi, dan telur serta bayam merah yang telah dihancurkan (3) Pengolahan mie. Standar resep pengolahan mie seperti pada Tabel 1.

Tabel 1. Standar Resep Mie

\begin{tabular}{|l|c|}
\hline \multicolumn{1}{|c|}{ Jenis Bahan } & $\sum$ Bahan \\
\hline Tepung terigu (g) & 1000 \\
\hline Tepung tapioka (g) & 100 \\
\hline Tepung pati (g) & 50 \\
\hline Telur (btr) & 8 \\
\hline Air (ml) & 375 \\
\hline Sumber : $\begin{array}{l}\text { Winarno, 2002Analisis } \\
\text { Kadar Zat Besi (Tejasari, } \\
\text { 2005) }\end{array}$
\end{tabular}


Mie kering hasil formulasi dianalisis kadar zat besi $(\mathrm{Fe})$ menggunakan metode spektrofotometri.

Analisis Kadar Serat (Sudarmadji d.k.k, 2007)

Kandungan serat dalam mie dianalisis menggunakan metode acid alkali digestion).

Analisis Kadar Air (Sudarmadji d.k.k, 2007)

Analisis kandungan air dalam mie dilakukan dengan metode oven.

\section{Analisis Mutu Organoleptik}

Uji mutu organoleptik dilakukan dengan menggunakan metode Hedonic Scale Test yang bertujuan untuk mengetahui daya terima terhadap mie kering dengan penambahan bayam merah.

\section{Analisis Mutu Fisik (Daya Putus)}

Prosedur analisis daya putus berdasarkan Tracker Elasticity Measurement menggunakan alat pengukur elastisitas.

\section{Penentuan Taraf Perlakuan Terbaik}

Penentuan taraf perlakuan terbaik menggunakan metode indeks efektifitas. Metode tersebut dilakukan dengan cara mengukur beberapa variabel yang mempengaruhi mutu mie kering yang dihasilkan seperti kadar zat besi, kadar serat, kadar air, dan mutu organoleptik.

\section{PENGOLAHAN DAN ANALISIS DATA}

Data Kadar Zat Besi, Kadar Serat, Kadar Air, dan Mutu Fisik (Daya Putus)

Pengolahan data kadar zat besi, kadar serat, kadar air dan daya putus mie kering dengan penambahan bayam merah bertujuan untuk mengetahui ada atau tidak adanya pengaruh perbedaan proporsi bayam merah terhadap kadar zat besi, kadar serat, kadar air dan daya putus dari masing-masing taraf perlakuan. Analisis data kadar zat besi, kadar serat, kadar air dan daya putus pada penelitian menggunakan analisis One Way Anova pada tingkat kepercayaan 95\%., dan digunakan uji lanjutan Duncan Multiple Range Test (DMRT) pada tingkat kepercayaan 95\%.

\section{Data Mutu Organoleptik}

Analisis mutu organoleptik ditentukan secara deskriptif dengan menggunakan nilai modus dari masingmasing taraf perlakuan. Sedangkan untuk mengetahui mutu organoleptik mie kering dengan penambahan bayam merah, digunakan analisis statistik Kruskall Wallis pada tingkat kepercayaan 95\%., dan uji lanjut dengan uji Mann Whitney.

\section{Data Penentuan Taraf Perlakuan Terbaik}

Hasil pengumpulan data dari masingmasing panelis ditabulasi sehingga diperoleh jumlah nilai masing-masing variabel dan rata-ratanya. Rangking variabel ditentukan berdasarkan nilai rata-rata masing-masing variabel dimana variabel yang memiliki rata-rata 
terbesar diberi rangking ke-1 dan variabel rata-rata terendah diberi rangking ke-8. Bobot variabel ditentukan dengan membagi nilai ratarata tiap variabel dengan rata-rata tertinggi. Variabel dengan nilai rata-rata semakin besar, maka rata-rata terendah sebagai nilai terjelek dan rata-rata tertinggi sebagai nilai terbaik

\section{HASIL DAN PEMBAHASAN}

\section{Kadar Zat Besi}

Kadar zat besi mie kering dengan penambahan bayam merah yang disajikan pada Tabel 2 menunjukkan bahwa semakin tinggi penambahan bayam merah maka kadar zat besi mie kering semakin meningkat. Menurut Dalimartha (2005), bayam merah memiliki kandungan zat besi yang tinggi. Kandungan zat besi tiap 100 gram bayam merah adalah $7 \mathrm{mg}$ (Atmarita, 2005). Hal tersebut yang menyebabkan peningkatan kadar zat besi pada mie kering bayam merah, sehingga penambahan bayam merah yang lebih banyak membuat kadar zat besi juga semakin meningkat. Mie kering dengan kadar zat besi yang memperoleh nilai tertinggi terdapat pada taraf perlakuan $\mathrm{P}_{5}$ (penambahan bayam merah $40 \%$ ) yaitu sebesar 4,97 mg dan kadar zat besi terendah terdapat pada taraf perlakuan $\mathrm{P}_{0}$ (penambahan bayam merah $0 \%$ ) yaitu sebesar 2,857 mg.
Tabel 2. Kadar Zat Besi Mie Kering Bayam Merah

\begin{tabular}{|c|c|}
\hline $\begin{array}{c}\text { Taraf Perlakuan } \\
\text { (Persentase } \\
\text { Penambahan } \\
\text { Bayam Merah) }\end{array}$ & $\begin{array}{c}\text { Rata-rata } \\
\text { Kadar Zat } \\
\text { Besi } \\
\text { (mg/100 g) }\end{array}$ \\
\hline $\mathrm{P}_{0}(0)$ & $2,857^{\mathrm{a}}$ \\
\hline $\mathrm{P}_{1}(20)$ & $3,978^{\mathrm{b}}$ \\
\hline $\mathrm{P}_{2}(25)$ & $4,100^{\mathrm{b}}$ \\
\hline $\mathrm{P}_{3}(30)$ & $4,681^{\mathrm{C}}$ \\
\hline $\mathrm{P}_{4}(35)$ & $4,858^{\mathrm{C}}$ \\
\hline $\mathrm{P}_{5}(40)$ & $4,970^{\mathrm{C}}$ \\
\hline Keterangan : Notasi yang berbeda \\
menunjukkan adanya \\
perbedaan $\begin{array}{c}\text { yang } \\
\text { signifikan }(\alpha=0,05)\end{array}$
\end{tabular}

Hasil analisis statistik One Way Anova pada tingkat kepercayaan 95\% menunjukkan bahwa terdapat pengaruh yang signifikan $(p=0,000)$ penambahan bayam merah terhadap kenaikan kadar zat besi mie kering yang dihasilkan. Hasil uji lanjut DMRT menunjukkan bahwa kadar zat besi mie kering tanpa penambahan bayam merah $\mathrm{P}_{0}$ secara statistik berbeda signifikan dengan mie kering taraf perlakuan $\mathrm{P}_{1}, \mathrm{P}_{2}, \mathrm{P}_{3}, \mathrm{P}_{4}$ dan $\mathrm{P}_{5}$, sedangkan kadar zat besi mie kering pada taraf perlakuan $\mathrm{P}_{1}$ dengan $\mathrm{P}_{2}$ serta pada taraf perlakuan $\mathrm{P}_{3}$ dengan $\mathrm{P}_{4}$ dan $\mathrm{P}_{5}$ secara statistik berbeda namun tidak signifikan. Hal tersebut dapat disebabkan karena pada saat memindahkan bubur bayam merah dari blender ke wadah lain, masih tersisa bubur bayam merah di dalam sela-sela blender karena terdapat bagian-bagian dalam blender yang susah dijangkau, sehingga mempengaruhi kadar zat besi mie bayam merah tiap perlakuan. Namun kadar zat besi mie bayam merah tersebut tidak terlalu berbeda antar perlakuan. Selain itu, perbedaan yang 
signifikan tersebut dapat disebabkan oleh umur bayam merah yang digunakan untuk mie kering bayam merah sedikit berbeda. Semakin tua bayam merah maka kadar zat besinya juga semakin meningkat.

Produk mie kering dalam penelitian mengandung zat besi 2,857 4,97 mg/100 gram bahan. Berdasarkan kandungan zat besinya yang cukup tinggi, mie kering bayam merah dapat dimanfaatkan untuk memenuhi kecukupan zat besi untuk wanita usia subur dan wanita hamil. Menurut Angka Kecukupan Gizi yang dianjurkan, kebutuhan zat besi untuk wanita usia subur dan wanita hamil adalah 26 mg/hari. Porsi penyajian mie kering bayam merah adalah sebesar 85 gram sehingga setiap kali penyajian dapat menyumbang kebutuhan zat besi berkisar antara 3,4 - 4,2 mg atau 13,1 $16,2 \%$ dari kecukupan zat besi yang dianjurkan.

\section{Kadar Serat}

Kadar serat mie kering dengan penambahan bayam merah yang disajikan pada Tabel 3 menunjukkan bahwa semakin tinggi penambahan bayam merah maka kadar serat mie kering semakin meningkat. Peningkatan kadar serat tersebut disebabkan karena bayam termasuk sayuran berserat tinggi sehingga penambahan bayam merah yang lebih banyak membuat kadar serat juga semakin meningkat (Rusilanti \& Kusharto, 2007).

$$
\text { Dalimartha (2005) juga }
$$

menyebutkan bahwa bayam termasuk sayuran berserat yang sangat dianjurkan untuk dikonsumsi oleh penderita kanker usus besar, penderita diabetes mellitus, kolesterol darah tinggi, dan menurunkan berat badan. Mie kering dengan kadar serat yang memperoleh nilai tertinggi terdapat pada taraf perlakuan $\mathrm{P}_{5}$ (penambahan bayam merah 40\%) yaitu sebesar 1,613 gram dan kadar serat terendah terdapat pada taraf perlakuan $\mathrm{P}_{0}$ (penambahan bayam merah $0 \%$ ) yaitu sebesar 0,903 gram.

\section{Tabel 3. Kadar Serat Mie Kering Bayam Merah}

\begin{tabular}{|c|c|}
\hline $\begin{array}{c}\text { Taraf Perlakuan } \\
\text { (Persentase } \\
\text { Penambahan Bayam } \\
\text { Merah) }\end{array}$ & $\begin{array}{c}\text { Rata-rata } \\
\text { Kadar Serat } \\
\mathbf{( g / 1 0 0 ~ g )}\end{array}$ \\
\hline $\mathrm{P}_{0}(0)$ & $0,903^{\mathrm{a}}$ \\
\hline $\mathrm{P}_{1}(20)$ & $1,261^{\mathrm{b}}$ \\
\hline $\mathrm{P}_{2}(25)$ & $1,323^{\mathrm{b}}$ \\
\hline $\mathrm{P}_{3}(30)$ & $1,432^{\mathrm{C}}$ \\
\hline $\mathrm{P}_{4}(35)$ & $1,525^{\mathrm{d}}$ \\
\hline $\mathrm{P}_{5}(40)$ & $1,613^{\mathrm{e}}$ \\
\hline Keterangan $:$ Notasi yang berbeda \\
menunjukkan adanya \\
perbedaan $\begin{array}{c}\text { yang } \\
\text { signifikan }(\alpha=0,05)\end{array}$
\end{tabular}

Hasil analisis statistik One Way Anova pada tingkat kepercayaan 95\% menunjukkan bahwa terdapat pengaruh yang signifikan $(p=0,000)$ penambahan bayam merah terhadap kenaikan kadar serat mie kering yang dihasilkan. Hasil uji lanjut DMRT menunjukkan bahwa kadar serat mie kering tanpa penambahan bayam merah $\mathrm{P}_{0}$ secara statistik berbeda signifikan dengan mie kering taraf perlakuan $\mathrm{P}_{1}, \mathrm{P}_{2}, \mathrm{P}_{3}, \mathrm{P}_{4}$ dan $\mathrm{P}_{5}$, sedangkan kadar serat mie kering pada taraf perlakuan $\mathrm{P}_{1}$ dengan $\mathrm{P}_{2}$ secara statistik berbeda namun tidak signifikan. Hal tersebut dapat disebabkan karena pada saat memindahkan bubur bayam merah dari blender ke wadah lain, masih tersisa bubur bayam merah di dalam sela-sela 
blender karena terdapat bagian-bagian dalam blender yang susah dijangkau, sehingga mempengaruhi kadar serat mie bayam merah tiap perlakuan. Namun kadar serat mie bayam merah tersebut tidak terlalu berbeda antar perlakuan.

Produk mie kering dalam penelitian mengandung serat 0,903 1,613 gram/100 gram bahan. Menurut Badan Kesehatan Dunia (WHO) adequate intake (AI) serat makanan yang bisa dijadikan acuan untuk menjaga kesehatan saluran pencernaan dan kesehatan organ tubuh lainnya bagi orang dewasa adalah sebesar 25 gram/hari. Porsi penyajian mie kering bayam merah adalah sebesar 85 gram sehingga setiap kali penyajian dapat menyumbang kebutuhan serat berkisar antara 1,07 - 1,37 gram atau 4,3 - 5,5\% dari kecukupan serat yang dianjurkan.

\section{Kadar Air}

Kadar air mie kering dengan penambahan bayam merah yang disajikan pada Tabel 4 menunjukkan bahwa semakin tinggi penambahan bayam merah maka kadar air mie kering cenderung semakin meningkat. Peningkatan kadar air tersebut disebabkan karena bayam termasuk sayuran yang mengandung kadar air yang cukup tinggi sehingga penambahan bayam merah yang lebih banyak membuat kadar air juga semakin meningkat. Menurut Atmarita (2005), kadar air bayam merah per 100 gram adalah sebesar 88,5 gram. Mie kering dengan nilai kadar air yang memperoleh nilai tertinggi terdapat pada taraf perlakuan $\mathrm{P}_{5}$ (penambahan bayam merah $40 \%$ ) yaitu sebesar $8,69 \%$ dan kadar air terendah terdapat pada taraf perlakuan $\mathrm{P}_{0}$ (penambahan bayam merah 0\%) yaitu sebesar 8,083\%.
Tabel 4. Kadar Air Mie Kering Bayam Merah

\begin{tabular}{|c|c|}
\hline $\begin{array}{c}\text { Taraf Perlakuan } \\
\text { (Persentase } \\
\text { Penambahan Bayam } \\
\text { Merah) }\end{array}$ & $\begin{array}{c}\text { Rata-rata } \\
\text { Kadar Air } \\
\mathbf{( \% )}\end{array}$ \\
\hline $\mathrm{P}_{0}(0)$ & $8,083^{\mathrm{a}}$ \\
\hline $\mathrm{P}_{1}(20)$ & $8,350^{\mathrm{b}}$ \\
\hline $\mathrm{P}_{2}(25)$ & $8,473^{\mathrm{c}}$ \\
\hline $\mathrm{P}_{3}(30)$ & $8,523^{\mathrm{cd}}$ \\
\hline $\mathrm{P}_{4}(35)$ & $8,613^{\mathrm{d}}$ \\
\hline $\mathrm{P}_{5}(40)$ & $8,690^{\mathrm{e}}$ \\
\hline Keterangan $\quad$ Notasi yang berbeda \\
menunjukkan adanya \\
perbedaan $\begin{array}{c}\text { yang } \\
\text { signifikan }(\alpha=0,05)\end{array}$
\end{tabular}

Hasil analisis statistik One Way Anova pada tingkat kepercayaan 95\% menunjukkan bahwa terdapat pengaruh yang signifikan $(\mathrm{p}=0,000)$ penambahan bayam merah terhadap kenaikan kadar air mie kering yang dihasilkan. Hasil uji lanjut DMRT menunjukkan bahwa kadar air mie kering taraf perlakuan $\mathrm{P}_{0}$ secara statistik berbeda signifikan dengan mie kering taraf perlakuan $\mathrm{P}_{1}$, $\mathrm{P}_{2}, \mathrm{P}_{3}, \mathrm{P}_{4}$ dan $\mathrm{P}_{5}$, sedangkan kadar air mie kering taraf perlakuan $\mathrm{P}_{3}$ dengan taraf perlakuan $\mathrm{P}_{2}$ dan $\mathrm{P}_{4}$ secara statistik berbeda namun tidak signifikan. Hal tersebut dapat disebabkan karena kesalahan prosedur saat analisis kadar air dilakukan.

Kadar air mempengaruhi daya tahan mie kering bayam merah. Winarno (2004) menjelaskan bahwa kadar air dalam bahan makanan mempengaruhi daya tahan makanan terhadap serangan mikroba. Semakin sedikit kadar air yang terdapat dalam bahan makanan maka umur simpan atau masa simpan makanan tersebut akan lebih panjang dibandingkan dengan 
bahan makanan yang memiliki kadar air lebih banyak. Menurut SNI 01-29741996, syarat kadar air untuk mie kering adalah maksimal 10\%. Hasil kadar air mie kering dalam penelitian adalah berkisar antara 8,083 - 8,69\% sehingga telah memenuhi standar yang telah ditentukan.

\section{MUTU ORGANOLEPTIK Tekstur}

Persentase tingkat kesukaan panelis yang menyatakan suka terhadap tekstur mie semakin besar yaitu dari $45 \%$ pada taraf perlakuan $\mathrm{P}_{0}$ (penambahan bayam merah 0\%) meningkat hingga $90 \%$ pada taraf perlakuan $\mathrm{P}_{5}$ (penambahan bayam merah 40\%). Selain itu, hasil uji kesukaan menunjukkan bahwa modus tingkat kesukaan terhadap tekstur mie kering bayam merah adalah suka (3). Persentase panelis yang menyatakan suka dan modus tingkat kesukaan terhadap tekstur mie kering bayam merah disajikan pada Tabel 5.

\section{Tabel 5. Persentase Panelis yang Menyatakan Suka dan Modus Tingkat Kesukaan terhadap Tekstur Mie Kering Bayam Merah}

\begin{tabular}{|c|c|c|}
\hline $\begin{array}{c}\text { Taraf } \\
\text { Perlakuan } \\
\text { (Persentase } \\
\begin{array}{c}\text { Penambahan } \\
\text { Bayam } \\
\text { Merah) }\end{array}\end{array}$ & $\begin{array}{c}\text { Jumlah } \\
\text { Panelis } \\
\text { (\%) }\end{array}$ & $\begin{array}{c}\text { Modus } \\
\text { Tingkat } \\
\text { Kesukaan }\end{array}$ \\
\hline $\mathrm{P}_{0}(0)$ & 45 & $2^{\mathrm{ab}}$ \\
\hline $\mathrm{P}_{1}(20)$ & 55 & $3^{\mathrm{ab}}$ \\
\hline $\mathrm{P}_{2}(25)$ & 65 & $3^{\mathrm{ac}}$ \\
\hline $\mathrm{P}_{3}(30)$ & 70 & $3^{\mathrm{b}}$ \\
\hline $\mathrm{P}_{4}(35)$ & 80 & $3^{\mathrm{abc}}$ \\
\hline $\mathrm{P}_{5}(40)$ & 90 & $3^{\mathrm{c}}$ \\
\hline
\end{tabular}

Tabel 5 menunjukkan bahwa semakin banyak bayam merah yang ditambahkan cenderung semakin tinggi tingkat kesukaan panelis terhadap tekstur mie kering bayam merah. Hal ini disebabkan semakin banyak bayam merah yang ditambahkan maka kadar air adonan juga semakin meningkat. Menurut Winarno (2002), dalam pembuatan mie, terdapat faktor-faktor yang mempengaruhi tekstur adonan, salah satunya adalah kadar air. Air di dalam adonan akan menyebabkan seratserat gluten mengembang, karena gluten menyerap air. Dengan peremasan terhadap adonan, serat-serat gluten ditarik sehingga terbentuk adonan yang lunak, kenyal serta elastis. Semakin banyak kadar air maka tekstur adonan juga akan semakin kenyal selama kadar air yang digunakan tidak melebihi batas maksimal daya serap tepung yang digunakan. Hal tersebut yang menyebabkan tingkat kesukaan panelis terhadap tekstur mie bayam merah semakin meningkat.

Berdasarkan besarnya persentase panelis dan modus tingkat kesukaan menunjukkan bahwa panelis suka terhadap tekstur mie bayam merah yang dihasilkan. Hasil analisis Kruskall Wallis pada tingkat kepercayaan 95\% menunjukkan bahwa terdapat pengaruh yang signifikan $(p=0,037)$ pada penambahan bayam merah terhadap tekstur mie kering yang dihasilkan. Hasil uji lanjut Mann Whitney menunjukkan bahwa tekstur mie kering pada taraf perlakuan $\mathrm{P}_{0}$ dengan $\mathrm{P}_{5}, \mathrm{P}_{1}$ dengan $\mathrm{P}_{5}, \mathrm{P}_{2}$ dengan $\mathrm{P}_{3}$, serta $\mathrm{P}_{3}$ dengan $\mathrm{P}_{5}$ menunjukkan perbedaan yang signifikan, sedangkan pada taraf perlakuan $\mathrm{P}_{0}$ dengan $\mathrm{P}_{1}, \mathrm{P}_{2}, \mathrm{P}_{3}$, dan $\mathrm{P}_{4}$, $\mathrm{P}_{1}$ dengan $\mathrm{P}_{2}, \mathrm{P}_{3}$, dan $\mathrm{P}_{4}, \mathrm{P}_{2}$ dengan $\mathrm{P}_{4}$ dan $\mathrm{P}_{5}, \mathrm{P}_{3}$ dengan $\mathrm{P}_{4}$, serta $\mathrm{P}_{4}$ dengan $\mathrm{P}_{5}$ 
menunjukkan perbedaan namun tidak signifikan. Perbedaan yang signifikan tersebut dapat disebabkan oleh hasil kadar air yang terdapat dalam mie bayam merah setelah dikeringkan antar perlakuan sedikit berbeda, sehingga mempengaruhi tekstur mie bayam merah setelah dimasak.

\section{Warna}

Persentase tingkat kesukaan panelis yang menyatakan suka terhadap warna mie semakin besar yaitu dari $60 \%$ pada taraf perlakuan $\mathrm{P}_{0}$ (penambahan bayam merah 0\%) meningkat hingga $85 \%$ pada taraf perlakuan $\mathrm{P}_{5}$ (penambahan bayam merah 40\%). Selain itu, hasil uji kesukaan menunjukkan bahwa modus tingkat kesukaan terhadap warna mie kering bayam merah adalah suka (3). Persentase panelis yang menyatakan suka dan modus tingkat kesukaan terhadap warna mie kering bayam merah disajikan pada Tabel 6 .

Tabel 6 menunjukkan bahwa semakin banyak bayam merah yang ditambahkan cenderung semakin tinggi tingkat kesukaan panelis terhadap warna mie kering bayam merah. Bayam merah mengandung zat berwarna merah yang mudah larut dalam air (Zumiati, 2009). Menurut Lingga (2010), warna merah pada bayam merah menunjukkan adanya antosianin yaitu pigmen yang berwarna merah keunguan. Antosianin berperan utama sebagai antioksidan. Antioksidan sangat diperlukan tubuh untuk mencegah terjadinya oksidasi radikal bebas yang menyebabkan berbagai macam penyakit. Zat tersebut juga yang menyebabkan mie kering berwarna merah. Semakin banyak penambahan bayam merah, mie akan semakin berwarna yang membuat penerimaan panelis terhadap warna mie bayam merah meningkat. Hasil tersebut sejalan dengan penelitian Rejeki (2008), bahwa penambahan bayam hijau menyebabkan warna mie bayam hijau semakin disukai, karena warna (kenampakan) makanan dapat memberikan petunjuk mengenai perubahan kimia dalam makanan.

Tabel 6. Persentase Panelis yang Menyatakan Suka dan Modus Tingkat Kesukaan terhadap Warna Mie Kering Bayam Merah

\begin{tabular}{|c|c|c|}
\hline $\begin{array}{c}\text { Taraf } \\
\text { Perlakuan } \\
\text { (Persentase } \\
\begin{array}{c}\text { Penambahan } \\
\text { Bayam } \\
\text { Merah) }\end{array}\end{array}$ & $\begin{array}{c}\text { Jumlah } \\
\text { Panelis } \\
\mathbf{( \% )}\end{array}$ & $\begin{array}{c}\text { Modus } \\
\text { Tingkat } \\
\text { Kesukaan }\end{array}$ \\
\hline $\mathrm{P}_{0}(0)$ & 60 & $2^{\mathrm{bc}}$ \\
\hline $\mathrm{P}_{1}(20)$ & 70 & $3^{\mathrm{b}}$ \\
\hline $\mathrm{P}_{2}(25)$ & 75 & $3^{\mathrm{c}}$ \\
\hline $\mathrm{P}_{3}(30)$ & 80 & $3^{\mathrm{a}}$ \\
\hline $\mathrm{P}_{4}(35)$ & 80 & $3^{\mathrm{bc}}$ \\
\hline $\mathrm{P}_{5}(40)$ & 85 & $3^{\mathrm{C}}$ \\
\hline
\end{tabular}

Berdasarkan besarnya persentase panelis dan modus tingkat kesukaan menunjukkan bahwa panelis suka terhadap warna mie bayam merah yang dihasilkan. Hasil analisis Kruskall Wallis pada tingkat kepercayaan 95\% menunjukkan bahwa terdapat pengaruh yang signifikan $(\mathrm{p}=0,000)$ pada penambahan bayam merah terhadap warna mie kering yang. Hasil uji lanjut Mann Whitney menunjukkan bahwa warna mie kering pada taraf perlakuan $\mathrm{P}_{0}$ dengan $\mathrm{P}_{3}, \mathrm{P}_{1}$ dengan $\mathrm{P}_{2}, \mathrm{P}_{3}$ dan $\mathrm{P}_{5}$, $\mathrm{P}_{2}$ dengan $\mathrm{P}_{3}$, serta $\mathrm{P}_{3}$ dengan $\mathrm{P}_{4}$ dan $\mathrm{P}_{5}$ menunjukkan perbedaan yang signifikan, sedangkan pada taraf 
perlakuan $\mathrm{P}_{0}$ dengan $\mathrm{P}_{1}, \mathrm{P}_{2}, \mathrm{P}_{4}$, dan $\mathrm{P}_{5}$, $\mathrm{P}_{1}$ dengan $\mathrm{P}_{4}, \mathrm{P}_{2}$ dengan $\mathrm{P}_{4}$ dan $\mathrm{P}_{5}$, serta $\mathrm{P}_{4}$ dengan $\mathrm{P}_{5}$ menunjukkan perbedaan namun tidak signifikan. Perbedaan yang signifikan tersebut dapat disebabkan oleh adanya antosianin yang memberikan warna merah pada bayam merah sedikit hilang saat proses pengukusan. Antosianin dapat larut dalam air, sehingga terdapat kemungkinan saat proses pengukusan antosianin sedikit larut bersama uap air dan menyebabkan warna mie bayam merah berbeda antar perlakuan.

\section{Aroma}

Persentase tingkat kesukaan panelis yang menyatakan suka terhadap aroma mie semakin kecil yaitu dari 85\% pada taraf perlakuan $\mathrm{P}_{0}$ (penambahan bayam merah 0\%) menurun hingga 65\% pada taraf perlakuan $\mathrm{P}_{5}$ (penambahan bayam merah $40 \%$ ). Selain itu, hasil uji kesukaan menunjukkan bahwa modus tingkat kesukaan terhadap aroma mie kering bayam merah adalah suka (3). Persentase panelis yang menyatakan suka dan modus tingkat kesukaan terhadap aroma mie kering bayam merah disajikan pada Tabel 7 .

Tabel 7 menunjukkan bahwa semakin banyak bayam merah yang ditambahkan cenderung semakin rendah tingkat kesukaan panelis terhadap aroma mie kering bayam merah. Aroma makanan banyak menentukan kelezatan bahan makanan tersebut (Winarno, 2002). Aroma mie kering bayam merah meningkat sejalan dengan peningkatan bayam merah yang ditambahkan. Akan tetapi, peningkatan bayam merah yang ditambahkan ke dalam mie mengakibatkan penurunan tingkat kesukaan terhadap aroma mie bayam merah. Hal ini dikarenakan aroma dari mie berbau khas bayam sehingga panelis kurang menyukai aroma mie bayam merah tersebut. Hasil tersebut sejalan dengan penelitian Rejeki (2008), semakin tinggi penambahan bayam dalam pembuatan mie bayam hijau maka aroma mie semakin tidak disukai.

\section{Tabel 7. Persentase Panelis yang Menyatakan Suka dan Modus Tingkat Kesukaan terhadap Aroma Mie Kering Bayam Merah}

\begin{tabular}{|c|c|c|}
\hline $\begin{array}{c}\text { Taraf } \\
\text { Perlakuan } \\
\text { (Persentase } \\
\text { Penambahan } \\
\text { Bayam } \\
\text { Merah) }\end{array}$ & $\begin{array}{c}\text { Jumlah } \\
\text { Panelis } \\
\mathbf{( \% )}\end{array}$ & $\begin{array}{c}\text { Modus } \\
\text { Tingkat } \\
\text { Kesukaan }\end{array}$ \\
\hline $\mathrm{P}_{0}(0)$ & 85 & 3 \\
\hline $\mathrm{P}_{1}(20)$ & 80 & 3 \\
\hline $\mathrm{P}_{2}(25)$ & 80 & 3 \\
\hline $\mathrm{P}_{3}(30)$ & 80 & 3 \\
\hline $\mathrm{P}_{4}(35)$ & 75 & 3 \\
\hline $\mathrm{P}_{5}(40)$ & 65 & 3 \\
\hline
\end{tabular}

Berdasarkan besarnya persentase panelis dan modus tingkat kesukaan menunjukkan bahwa panelis suka terhadap aroma mie bayam merah yang dihasilkan. Hasil analisis Kruskall Wallis pada tingkat kepercayaan 95\% menunjukkan bahwa terdapat pengaruh yang tidak signifikan $(p=0,674)$ pada penambahan bayam merah terhadap aroma mie kering yang dihasilkan.

\section{Rasa}

Persentase tingkat kesukaan panelis yang menyatakan suka terhadap rasa mie semakin besar yaitu dari 50\% pada taraf perlakuan $\mathrm{P}_{0}$ (penambahan bayam merah $0 \%$ ) meningkat hingga 95\% pada taraf perlakuan $\mathrm{P}_{5}$ (penambahan bayam merah 40\%). 
Selain itu, hasil uji kesukaan menunjukkan bahwa modus tingkat kesukaan terhadap rasa mie kering bayam merah adalah suka (3). Persentase panelis yang menyatakan suka dan modus tingkat kesukaan terhadap rasa mie kering bayam merah disajikan pada Tabel 8.

\section{Tabel 8. Persentase Panelis yang Menyatakan Suka dan Modus Tingkat Kesukaan terhadap Rasa Mie Kering Bayam Merah}

\begin{tabular}{|c|c|c|}
\hline $\begin{array}{c}\text { Taraf } \\
\text { Perlakuan } \\
\text { (Persentase } \\
\text { Penambahan } \\
\text { Bayam } \\
\text { Merah) }\end{array}$ & $\begin{array}{c}\text { Jumlah } \\
\text { Panelis } \\
\mathbf{( \% )}\end{array}$ & $\begin{array}{c}\text { Modus } \\
\text { Tingkat } \\
\text { Kesukaan }\end{array}$ \\
\hline $\mathrm{P}_{0}(0)$ & 50 & $2^{\mathrm{a}}$ \\
\hline $\mathrm{P}_{1}(20)$ & 60 & $3^{\mathrm{ab}}$ \\
\hline $\mathrm{P}_{2}(25)$ & 70 & $3^{\mathrm{b}}$ \\
\hline $\mathrm{P}_{3}(30)$ & 75 & $3^{\mathrm{ab}}$ \\
\hline $\mathrm{P}_{4}(35)$ & 85 & $3^{\mathrm{b}}$ \\
\hline $\mathrm{P}_{5}(40)$ & 95 & $4^{\mathrm{c}}$ \\
\hline
\end{tabular}

Tabel 8 menunjukkan bahwa semakin banyak bayam merah yang ditambahkan cenderung semakin tinggi tingkat kesukaan panelis terhadap rasa mie kering bayam merah. Rasa merupakan faktor penting dalam menentukan daya terima suatu produk. Tekstur, warna, dan aroma yang baik apabila tidak disertai dengan rasa yang enak maka produk tersebut tidak akan diterima. Rasa mie bayam merah meningkat sejalan dengan peningkatan bayam merah yang ditambahkan sehingga tingkat kesukaan terhadap rasa mie bayam merah juga meningkat. Hal ini dikarenakan penambahan bayam merah kedalam mie kering membuat peningkatan citarasa dari kandungan glutamat yang terdapat didalam bayam merah. Menurut Wikipedia, kandungan glutamat dalam bayam adalah 48 mg/100 gram bahan. Glutamat merupakan salah satu dari 20 asam amino penyusun protein. Glutamat dalam bentuk bebas memiliki rasa Umami (gurih). Dengan demikian, semakin tinggi kandungan glutamat bebas dalam suatu makanan maka semakin kuat rasa umaminya.

Berdasarkan besarnya persentase panelis dan modus tingkat kesukaan menunjukkan bahwa panelis suka terhadap rasa mie bayam merah yang dihasilkan. Hasil analisis Kruskall Wallis pada tingkat kepercayaan 95\% menunjukkan bahwa terdapat pengaruh yang signifikan $(\mathrm{p}=0,000)$ pada penambahan bayam merah terhadap rasa mie kering yang dihasilkan. Hasil uji lanjut Mann Whitney menunjukkan bahwa rasa mie kering pada taraf perlakuan $\mathrm{P}_{0}$ dengan $\mathrm{P}_{2}, \mathrm{P}_{4}$, dan $\mathrm{P}_{5}, \mathrm{P}_{1}$ dengan $\mathrm{P}_{5}, \mathrm{P}_{2}$ dengan $\mathrm{P}_{5}, \mathrm{P}_{3}$ dengan $\mathrm{P}_{5}$, serta $\mathrm{P}_{4}$ dengan $\mathrm{P}_{5}$ menunjukkan perbedaan yang signifikan, sedangkan pada taraf perlakuan $\mathrm{P}_{0}$ dengan $\mathrm{P}_{1}$ dan $\mathrm{P}_{3}, \mathrm{P}_{1}$ dengan $\mathrm{P}_{2}, \mathrm{P}_{3}$, dan $\mathrm{P}_{4}, \mathrm{P}_{2}$ dengan $\mathrm{P}_{3}$ dan $\mathrm{P}_{4}$, serta $\mathrm{P}_{3}$ dengan $\mathrm{P}_{4}$ menunjukkan perbedaan namun tidak signifikan. Hal tersebut dapat disebabkan karena umur bayam merah yang digunakan untuk pengolahan mie kering. Umur bahan makanan dapat mempengaruhi kandungan glutamat di dalam bahan makanan tersebut. Menurut Wikipedia, salah satu contoh bahan makanan yang tinggi glutamat adalah tomat. Kandungan glutamat dalam tomat meningkat seiring dengan proses pematangan tomat. Hal tersebut juga terjadi pada proses pematangan bayam merah. Oleh karena itu, terdapat 
kemungkinan kandungan glutamat antar perlakuan sedikit berbeda yang menyebabkan perbedaan signifikan antar perlakuan tertentu.

\section{Mutu Fisik (Daya Putus)}

Daya putus merupakan besarnya gaya tiap satuan luas penampang bahan yang dibutuhkan untuk memutuskan suatu produk (Yuwono, 1998 dalam Kusrini, 2008). Nilai daya putus mie kering dengan penambahan bayam merah yang disajikan pada Tabel 9 menunjukkan bahwa semakin tinggi penambahan bayam merah maka gaya yang diberikan semakin meningkat. Semakin tinggi gaya yang diberikan menunjukkan mie semakin elastis (Yuwono, 1998 dalam Kusrini, 2008).

Peningkatan nilai daya putus tersebut disebabkan semakin banyak bayam merah yang ditambahkan maka kadar air adonan juga semakin meningkat. Menurut Winarno (2002), dalam pembuatan mie, terdapat faktorfaktor yang mempengaruhi tekstur adonan, salah satunya adalah kadar air. Air memungkinkan terbentuknya gluten (kandungan protein). Gluten dapat terbentuk apabila protein tepung dicairkan dengan air (U.S Wheat Associates, 1981). Air di dalam adonan akan menyebabkan serat-serat gluten mengembang, karena gluten menyerap air. Dengan peremasan terhadap adonan, serat-serat gluten ditarik sehingga terbentuk adonan yang lunak, kenyal serta elastis. Semakin sedikit penambahan bayam merah maka mie bayam merah akan semakin mudah putus. Mie bayam merah yang paling tidak mudah putus terdapat pada taraf perlakuan $\mathrm{P}_{5}$ (penambahan bayam merah $40 \%$ ) dengan nilai daya putus sebesar 1,781 N/g dan mie bayam merah yang paling mudah putus terdapat pada taraf perlakuan $\mathrm{P}_{0}$ (penambahan bayam merah $0 \%$ ) dengan nilai daya putus sebesar 1,648 N/g.

\section{Tabel 9. Daya Putus Mie Kering Bayam Merah}

\begin{tabular}{|c|c|}
\hline $\begin{array}{c}\text { Taraf Perlakuan } \\
\text { (Persentase } \\
\text { Penambahan } \\
\text { Bayam Merah) }\end{array}$ & $\begin{array}{c}\text { Rata-rata } \\
\text { Daya Putus } \\
\text { (N/g) }\end{array}$ \\
\hline $\mathrm{P}_{0}(0)$ & $1,648^{\mathrm{a}}$ \\
\hline $\mathrm{P}_{1}(20)$ & $1,718^{\mathrm{ab}}$ \\
\hline $\mathrm{P}_{2}(25)$ & $1,748^{\mathrm{b}}$ \\
\hline $\mathrm{P}_{3}(30)$ & $1,740^{\mathrm{b}}$ \\
\hline $\mathrm{P}_{4}(35)$ & $1,764^{\mathrm{b}}$ \\
\hline $\mathrm{P}_{5}(40)$ & $1,781^{\mathrm{b}}$ \\
\hline
\end{tabular}

Keterangan : Notasi yang berbeda menunjukkan adanya perbedaan yang signifikan $(\alpha=0,05)$

Hasil analisis statistik One Way Anova pada tingkat kepercayaan 95\% menunjukkan bahwa terdapat pengaruh yang signifikan $(p=0,046)$ pada penambahan bayam merah terhadap kenaikan nilai daya putus mie kering yang dihasilkan. Hasil uji lanjut DMRT menunjukkan bahwa nilai daya putus mie kering tanpa penambahan bayam merah $\mathrm{P}_{0}$ secara statistik berbeda signifikan dengan mie kering taraf perlakuan $\mathrm{P}_{2}, \mathrm{P}_{3}, \mathrm{P}_{4}$ dan $\mathrm{P}_{5}$, namun berbeda tidak signifikan dengan mie kering taraf perlakuan $\mathrm{P}_{1}$. Nilai daya putus mie kering taraf perlakuan $\mathrm{P}_{2}$ dengan $\mathrm{P}_{3}, \mathrm{P}_{4}$ dan $\mathrm{P}_{5}$ secara statistik berbeda namun tidak signifikan.

Produk mie kering dalam penelitian mengandung nilai daya putus $1,648-1,781 \quad$ N/g. Apabila dibandingkan dengan mie kering komersial seperti mie telur cap 3 ayam yang memiliki nilai daya putus sebesar 
2,17 N/g, maka nilai daya putus mie kering bayam merah masih dibawah nilai daya putus mie kering komersial. Hal ini dapat disebabkan karena jumlah bahan tambahan dalam pengolahan mie seperti Carboxy Methil Cellulose (CMC) yang digunakan kadarnya lebih tinggi. Menurut Purnawijayanti (2009), CMC berfungsi membentuk mie yang liat dan kenyal sehingga tidak mudah putus. Penggunaan CMC pada umumnya dapat digunakan sebanyak 0,5 - 1\%. Dalam penelitian, kadar CMC yang digunakan untuk pembuatan mie kering bayam merah adalah $0,5 \%$ dari berat tepung. Kadar CMC yang digunakan oleh mie kering komersial dapat lebih tinggi karena terdapat rentang dalam penggunaan CMC sampai 1\%. Hal tersebut yang dapat menyebabkan nilai daya putus mie komersial lebih tinggi dari mie kering bayam merah.

\section{Perlakuan Terbaik}

Hasil tabulasi data terhadap variabel-variabel yang mempengaruhi mie kering menunjukkan bahwa kadar zat besi merupakan variabel terpenting yang memiliki nilai paling tinggi, sedangkan variabel kedua yang dianggap penting oleh panelis pada mie kering adalah kadar air. Produk makanan untuk ibu hamil harus memiliki kadar zat besi yang tinggi. Hal ini disebabkan kebutuhan zat besi untuk wanita dalam usia subur dan untuk wanita hamil lebih tinggi daripada untuk laki-laki. Fungsi utama dari zat besi adalah dalam formasi hemoglobin di dalam sel darah merah. Hemoglobin memiliki fungsi yang sangat penting yaitu membawa oksigen ke seluruh tubuh (Marks, 1970). Sel membutuhkan oksigen untuk memecah glukosa dan menghasilkan energi. Zat besi juga merupakan bagian dari myoglobin, sebuah protein otot yang menyimpan dan membawa oksigen. Zat besi bekerja dengan banyak enzim dalam metabolisme energi dan diperlukan untuk membuat sel baru seperti halnya hormon-hormon tertentu dan neurotransmitter (Drummond, 1997).

Taraf perlakuan $\mathrm{P}_{5}$ (penambahan bayam merah $40 \%$ ) memiliki total nilai hasil (Nh) tertinggi yaitu sebesar 0,97. Mie kering dengan penambahan bayam merah 35\% (taraf perlakuan $\mathrm{P}_{4}$ ) memiliki total nilai hasil tertinggi kedua yaitu sebesar 0,76 diikuti taraf perlakuan $\mathrm{P}_{2}, \mathrm{P}_{1}, \mathrm{P}_{3}$ dan $\mathrm{P}_{0}$ dengan total nilai hasil masing-masing sebesar 0,7 ; 0,52; 0,46 dan 0,18. Perlakuan dengan total nilai hasil (Nh) tertinggi merupakan perlakuan terbaik. Berdasarkan hasil perhitungan total nilai hasil maka mie kering dengan penambahan bayam merah 40\% (taraf perlakuan $\mathrm{P}_{5}$ ) adalah mie kering dengan perlakuan terbaik yang memiliki kadar zat besi sebesar 4,97 miligram/100 gram bahan, kadar serat 1,613 gram/100 gram bahan, kadar air 8,69 gram/100 gram bahan, nilai daya putus 1,781 N/g dan jumlah konsumen yang menyatakan suka sebanyak 90\% terhadap tekstur mie kering bayam merah, 85\% terhadap warna mie kering bayam merah, 65\% terhadap aroma mie kering bayam merah, serta 95\% terhadap rasa mie kering bayam merah. Karakteristik mie kering bayam merah pada taraf perlakuan $\mathrm{P}_{5}$ (penambahan bayam merah 40\%) disajikan pada Tabel 21. 
Tabel 10. Karakteristik Mie Kering Bayam Merah pada Taraf Perlakuan $\mathbf{P}_{5}$

\begin{tabular}{|l|c|}
\hline \multicolumn{1}{|c|}{ Karakteristik } & $\begin{array}{c}\text { Jumlah per } \\
\mathbf{1 0 0} \text { g Bahan }\end{array}$ \\
\hline Kadar Zat Besi & $4,97 \mathrm{mg}$ \\
\hline Kadar Serat & $1,613 \mathrm{~g}$ \\
\hline Kadar Air & $8,69 \mathrm{~g}$ \\
\hline Daya Putus & $1,781 \mathrm{~N} / \mathrm{g}$ \\
\hline
\end{tabular}

Karakteristik mie kering pada taraf perlakuan $\mathrm{P}_{5}$ (penambahan bayam merah 40\%) meliputi kadar zat besi, kadar serat, kadar air, dan daya putus. Menurut Angka Kecukupan Gizi yang dianjurkan, kebutuhan zat besi untuk wanita usia subur dan wanita hamil adalah $26 \mathrm{mg} / \mathrm{hari}$. Porsi penyajian mie kering bayam merah adalah sebesar 85 gram sehingga untuk taraf perlakuan $\mathrm{P}_{5}$, setiap kali penyajian dapat menyumbang kebutuhan zat besi sebesar 4,2 $\mathrm{mg}$ atau $16,2 \%$ dari kecukupan zat besi yang dianjurkan.

Menurut Badan Kesehatan Dunia (WHO), adequate intake (AI) serat makanan yang bisa dijadikan acuan untuk menjaga kesehatan saluran pencernaan dan kesehatan organ tubuh lainnya bagi orang dewasa adalah sebesar 25 gram/hari. Porsi penyajian mie kering bayam merah adalah sebesar 85 gram sehingga untuk taraf perlakuan $\mathrm{P}_{5}$, setiap kali penyajian dapat menyumbang kebutuhan serat sebesar 1,37 gram atau 5,5\% dari kecukupan serat yang dianjurkan.

Mie kering bayam merah pada taraf perlakuan $\mathrm{P}_{5}$ (penambahan bayam merah 40\%) dapat digunakan sebagai sumber pemenuhan zat besi, namun mie kering bayam merah pada taraf perlakuan $\mathrm{P}_{5}$ belum bisa digunakan sebagai sumber pemenuhan serat.
Menurut Kristianto (2010), suatu makanan dapat dikatakan sebagai sumber suatu zat gizi apabila \% AKG zat gizinya $>10 \%$ setiap porsi penyajian. Taraf perlakuan $\mathrm{P}_{5}$ menyumbangkan kebutuhan serat 5,5\% dari AKG setiap porsi penyajian sehingga belum memenuhi persyaratan yang ada. Menurut SNI 01-2974-1996, syarat kadar air untuk mie kering adalah maksimal 10\%. Hasil kadar air mie kering bayam merah untuk taraf perlakuan $\mathrm{P}_{5}$ adalah sebesar 8,69\% sehingga telah memenuhi standar yang telah ditentukan.

\section{KESIMPULAN DAN SARAN \\ Kesimpulan}

Penambahan bayam merah dalam pengolahan mie kering memberikan pengaruh yang nyata terhadap kadar zat besi mie kering bayam merah, semakin tinggi penambahan bayam merah maka kadar zat besi mie kering bayam merah semakin meningkat.

Penambahan bayam merah dalam pengolahan mie kering memberikan pengaruh yang nyata terhadap kadar serat mie kering bayam merah, semakin tinggi penambahan bayam merah maka kadar serat mie kering bayam merah semakin meningkat.

Penambahan bayam merah dalam pengolahan mie kering memberikan pengaruh yang nyata terhadap kadar air mie kering bayam merah, semakin tinggi penambahan bayam merah maka kadar air mie kering bayam merah semakin meningkat.

Penambahan bayam merah dalam pengolahan mie kering memberikan pengaruh yang nyata terhadap tekstur, warna dan rasa mie kering bayam merah, namun penambahan bayam merah dalam pengolahan mie kering 
tidak memberikan pengaruh yang nyata terhadap aroma mie kering bayam merah.

Penambahan bayam merah dalam pengolahan mie kering memberikan pengaruh yang nyata terhadap daya putus mie kering bayam merah, semakin tinggi penambahan bayam merah maka gaya yang diberikan semakin meningkat (mie semakin elastis).

Taraf perlakuan $\mathrm{P}_{5}$ (penambahan bayam merah 40\%) merupakan taraf perlakuan terbaik dalam produk mie kering yang memiliki kadar zat besi sebesar 5,0 miligram/100 gram bahan, kadar serat 1,6 gram/100 gram bahan, kadar air 8,69 gram/100 gram bahan, dan nilai daya putus $1,78 \mathrm{~N} / \mathrm{g}$.

\section{Saran}

1. Taraf perlakuan $\mathrm{P}_{5}$ (penambahan bayam merah 40\%) dapat dimanfaatkan sebagai makanan sumber pemenuhan zat besi untuk mencegah dan mengatasi anemia zat bes.

2. Perlu dilakukan uji lanjut tentang penentuan umur simpan mie kering bayam merah.

3. Perlu dilakukan penelitian terhadap pengembangan mie kering dengan penambahan produk hasil pertanian yang lain, sehingga menambah nilai gizi produk tersebut.

\section{DAFTAR PUSTAKA}

Amiruddin, Ridwan, d.k.k. (2007) Anemia Defisiensi Zat Besi Pada Ibu Hamil di Indonesia, [Online], Available http://ridwanamiruddin.wordpress .com [Oktober 2010]
Atmarita. (2005) Daftar Komposisi Bahan Makanan. Persagi, Jakarta

Brown, Judith E. (2005) Nutrition Through The Life Cycle, Second Edition. Thomson Wadsworth, Victoria

Dalimartha, Setiawan. (2005) Atlas Tumbuhan Obat Indonesia, Jilid 2. Trubus Agriwidya, Jakarta

Doktersehat.com. 2012. Kasiat Bayam Merah. http://doktersehat.com/khasiatbayam-merah.

Drummond, Karen Eich. (1997) Nutrition for The Food Service Professional, Third Edition. John Wiley \& Sons, inc, New York

Husaini, Mahidin Anwar. (1989) Study Nutritional Anemia An Assessment of Information Compilation For Supporting and Formulating National Policy and Program. Direktorat Bina Gizi Masyarakat Dep. Kes, Jakarta

Kementrian Pertanian Republik Indonesia. (2010) Produksi Bayam Nasional. [Online], Available http://database.deptan.go.id/bdsp/ hasilKom.asp [Desember 2010]

Kristianto, Yohanes. (2010) Panduan Memilih dan Belanja Makanan Sehat. Resist Book, Yogyakarta

Kusrini, Yulia. (2008) Studi Pembuatan Mie Kering (Kajian Proporsi Tepung Kasava Terfermentasi dan Penambahan Gluten Kering). [Online], Available www.lordbroken.wordpress.com [Desember 2010]

Lingga, Lanny. (2010) Cerdas Memilih Sayuran. AgroMedia Pustaka, Jakarta 
Marks, Harriet. (1970) Nutrition and Elementary Food Science. The Jacaranda Press, Hongkong

Purnawijayanti, Hiasinta A. (2009) Mie Sehat. Penerbit Kanisius, Yogyakarta

Rusilanti dan Kusharto, Clara M. (2007) Sehat dengan Makanan Berserat. PT Agro Media Pustaka, Jakarta

SNI 01-2974-1996. Mi Kering. Badan Standardisasi Nasional, Jakarta

Subijakto, Achmad. (2010) Gemarikan, Mie Instan dan Gerakan Sehari Tanpa Nasi. [Online], Available: www.dkp.go.id/archives/pdf/30/3 463/ gemarikan-mie-instan-dangerakan-sehari-tanpa$\underline{\text { nasi/+gemarikan, }+ \text { mie+ instan.pdf }}$ [Desember 2010]

Tejasari. (2005) Nilai Gizi Pangan. Graha Ilmu, Jakarta

U.S Wheat Associates. (1981) Pedoman Pembuatan Roti dan Kue. Penerbit Djambatan, Jakarta

Wikipedia Ensiklopedia Bebas. Mononatrium Glutamat, [Online], Available http://id.wikipedia.org/wiki/Mono natrium_glutamat [Juli 2011]

Winarno, Florentinus Gregorius. (2002) Buku Putih Panduan Tanya Jawab Tentang Mi Instan untuk Kalangan Akademik, Cetakan Pertama. M-Brio Press, Bogor

Winarno, Florentinus Gregorius. (2002) Kimia Pangan dan Gizi. Gramedia Pustaka Umum, Jakarta

Yuwono, S. S. dan Susanto, T. (2001) Pengujian Fisik Pangan. Fakultas Teknologi Pertanian Universitas Brawijaya, Malang.

Zumiati, Setijo Pitojo. (2009) Pewarna Nabati Makanan. Penerbit Kanisius, Yogyakarta 